\title{
Feed management and stocking density of the endangered wild zebra pleco: Implications for captive breeding
}

\author{
Fabrício Menezes Ramos ${ }^{1,2}$ | Higo Andrade Abe ${ }^{2}$ (D) | Carlos Alberto Martins Cordeiro ${ }^{3}$ | \\ Luis André Luz Barbas ${ }^{2,4}$ (D) | Paulo César Falanghe Carneiro ${ }^{5}$ | Alexandre Nizio Maria ${ }^{5}$ | \\ Rodrigo Yudi Fujimoto ${ }^{5}$
}

${ }^{1}$ Aquatic Organisms Laboratory of Low Tocantins (AQUANTINS), Federal Institute of Education, Science and Technology of Pará (IFPA), Cametá, Brazil

${ }^{2}$ Post-Graduation Programme in Animal Science, Federal University of Pará, Belém, Brazil

${ }^{3}$ Federal University of Pará, Bragança, Brazil

${ }^{4}$ Tropical Species Aquaculture Laboratory (LAET), Federal Institute of Education, Science and Technology of Pará (IFPA), Castanhal, Brazil

${ }^{5}$ Brazilian Agricultural Research Corporation (EMBRAPA), Aracaju, Brazil

Correspondence

Rodrigo Yudi Fujimoto, Brazilian Agricultural Research Corporation (EMBRAPA), Av. Beira Mar 3250, 49025-040, Aracaju, Sergipe, Brazil.

Email: ryfujim@hotmail.com

Funding information

Norte Energia SA; Leme Engenharia; CNPq, Grant/Award Number: 406512/2012-4 and 305195/2016-6

\begin{abstract}
Due to the economic potential of Hypancistrus zebra in the ornamental fish market and its current classification as an endangered species in its natural occurrence sites, the present study sought to determine a suitable feed management strategy and stocking density to allow for an adequate captivity maintenance of this fish species. Three experiments were conducted as follows: (1) feed preference (artemia Artemia sp., shrimp Litopenaeus vannamei, fish Cynoscion spp. or mussel Perna perna); (2) determination of feeding rate ( $5 \%$ and $10 \%$ live weight day $\left.{ }^{-1}\right)$ and frequency $(1,2$ or 3 meals. Day $\left.{ }^{-1}\right)$; and (3) evaluation of stocking density $(0.25,0.50,1.00$ and $2.00 \mathrm{~g} / \mathrm{L})$. Zebra pleco did not present the characteristic buccal scraping behaviour on the feed, commonly seen in other Loricariids. Artemia was the preferred diet followed by fish, shrimp and mussels. The frequency of two daily meals and the feeding rate of $10 \%$ live weight day $^{-1}$ allowed for an improved zootechnical performance. Zebra pleco showed enhanced specific growth rate at the density of $2 \mathrm{~g} / \mathrm{L}$. Our results suggest that, to improve the zebra pleco rearing conditions, it should be maintained at a density of $2 \mathrm{~g} / \mathrm{L}$, fed two daily meals at a feeding rate of $10 \%$ live weight day ${ }^{-1}$. These findings correspond to useful information for an adequate management of this species and could assist in the supply of healthy specimens to the ornamental fish market as well for the restocking of declining wild populations.
\end{abstract}

KEYWORDS

Amazon fish, behaviour, feed preference, feeding rate

\section{1 | INTRODUCTION}

Among the Amazonian ornamental fish taxa, the Loricariidae stands out as the most important family, in which the Hypancistrus zebra Isbrücker \& Nijssen, 1991, popularly known as zebra pleco is included. This species has great economic and biological importance for the Xingu River basin and there is an unmet demand for the development of captive breeding technology (Ramos, Araújo, Prang,
\& Fujimoto, 2015). The zebra pleco is a vulnerable and critically endangered endemic species to the Xingu river (Normative Instruction 05/2004 of the Environment Ministry, Brazil), being protected under the Decree Law 802/2008 issued by the Environment Secretariat of Pará State. Although fishing of this species is prohibited in Brazil, the illegal trade is a recurrent practice (Gonçalves et al., 2009), and each individual can reach an international market value of up to US\$450 (LiveAquaria, 2016). 
The high market value of fish from the Loricariidae family has boosted the search for improved captive breeding technologies (Gonçalves et al., 2009), yet relatively few breeding protocols are available for the commercial production of these species (Ramos et al., 2015). The captive breeding of zebra pleco is important not only from a preservation perspective, that is, for the protection of natural fish stocks, but also for the supply of the ornamental fish market which is under constant expansion worldwide (ITC, 2018; MDIC, 2017). Hence, basic information about the feeding management of this species should be made available. In nature, the zebra pleco diet encompasses a broad feed spectrum, including a high frequency of small animal-based feed, periphytic algae, sponges and debris (Gonçalves, 2011). Such a high food plasticity allows for a presumably easier captive breeding condition, as low-cost diets made of over-the-counter and readily available ingredients could be used (Gerking, 1994).

Feed preference tests are indicated to provide subsidies for appropriate diet formulations in captivity (Sullivan, Lawrence, \& Blache, 2016; Volpato, Goncalves-de-Freitas, \& Fernandes-de-Castilho, 2007), and in addition to the determination of feed preference, fish must be reared in the absence of pain and severe stress, for these conditions will contribute to an improved welfare status (Volpato et al., 2007). In fact, there is an indisputable public concern about animal husbandry practices and welfare-related issues (Huntingford et al., 2006). Studies on feed preference and feed management strategies have been reported for other endangered aquatic species, as the fish (Chitala chitala; Sarkar et al., 2006) and the axolotl (Ambystoma mexicanum; Slight, Nichols, \& Arbuckle, 2015).

In addition to the inherent food plasticity of the species, efficient feed management practices can be cost- and time-effective (Carneiro \& Mikos, 2005; Crescêncio et al., 2005; Ribeiro, Carvalho Junior, Fernandes, \& Nakayama, 2008). In this sense, adjusting the feeding rate and frequency could secure more positive yields in fish farming.

An adequate stocking density is equally important for attaining improved yields, as it interferes with feeding behaviour and modulates animal growth (Lefrançois, Claireaux, Merciel, \& Aubin, 2001). High stocking densities and overfeeding may impair the water quality (Fujimoto, De Castro, De Moares, \& Ramos, 2012; Sahoo, Giri, Chandra, \& Sahu, 2010), reduce nutrient utilization, reproductive rates (Papoutsoglou, Tziha, Vrettos, \& Athanasiou, 1998) and decrease survival (Ribeiro, Jorge, Fernandes, \& Sakomura, 2010; Zuanon, Salaro, \& Furuya, 2011). However, the increase in stocking density of bagrid catfish (Mystus nemurus) promoted higher survival rates and reflected a higher productivity per area (Rahmah et al., 2014). It has been emphasized that higher stocking densities should be sought after as it can increase the biomass, and consequently improve the yields and the financial return (Rahman, Kazi Ahsan Habib, Amzad Hossain, Azad, \& Rayhan, 2017; Shoko, Limbu, \& Mgaya., 2016).

In this sense, the present study aimed at evaluating the feed preference and the effect of different feeding strategies and stocking densities on the growth performance of captive zebra pleco H. zebra.

\section{2 | MATERIAL AND METHODS}

Three experiments were carried out with adult specimens of zebra pleco captured in the municipality of Altamira (State of Pará, Brazil) between the locality of Gorgulho de Rita and Vila de Belo Monte (authorization SISBIO 38.215-2 and Animal Ethics Committee Protocol \# 03.14.00.017.00.00). These animals were acclimated in the Ornamental Fish Laboratory of the Centre for Environmental Studies, North Energy, Vitoria do Xingu - PA, stocked at the density of 30 individuals per 200- $\mathrm{L}$ in aquariums equipped with two biological filters at a flow rate of $200 \mathrm{~L} / \mathrm{hr}$ for 20 days. During the acclimation period, a preliminary test was carried out with several foods: potato, cucumber, pumpkin, lettuce and cabbage, artemia, fish fillets, shrimp and mussels as well as microalgae. The feed was supplied in natura, frozen and crushed. Upon administration, the feed was weighed and provided in $1 \mathrm{~g}$ portions. Feed acceptance was evaluated through the observation of active search for feed particles and consumption, that is, effective ingestion.

\subsection{Environmental conditions during the experiments}

Fish were distributed to the experimental aquariums and allowed to acclimate for 7 days, using the same feeding regimen of the preliminary test. A biological filter $(100 \mathrm{~L} / \mathrm{hr})$ and a heater $(100 \mathrm{~W})$ were connected to the aquariums which were kept under constant aeration. Partial water changes of $30 \%$ were performed daily for the removal of uneaten food and faeces.

Water $\mathrm{pH}$, temperature, dissolved oxygen and electrical conductivity (Instrutherm $\left.{ }^{\mathrm{TM}} \mathrm{PH}-1500\right)$ were monitored daily. Total ammonia was monitored each 3 days using spectrophotometry analysis (Hanna ${ }^{\mathrm{TM}}$ HI 93715).

\section{2 | Experiment 1: Feed preference test}

From the preliminary tests, the feeds were selected for the definitive preference assay. A completely randomized design with four diets and eight replicates each was used. The diets consisted of the following feeds: artemia Artemia sp., shrimp Litopenaeus vannamei, mussel Perna perna and fish Cynoscion spp. The feed was frozen, crushed and weighed in $1 \mathrm{~g}$ portions.

Eight specimens ( $3.46 \pm 0.37 \mathrm{~g}$ and $6.52 \pm 0.84 \mathrm{~cm}$, adults) were randomly selected and individually allocated in each experimental aquarium $(45 \times 45 \mathrm{~cm})$ with $50 \mathrm{~L}$ of water (useful volume) with constant artificial oxygenation and heating to maintain the temperature at $28^{\circ} \mathrm{C}$. Each aquarium was occupied by one fish only, to minimize the effect of competitive interactions among individuals (Ramos et al., 2013) and each animal was considered a replicate. To avoid a completely barren environment (Ramos et al., 2013), a cross-shaped PVC shelter with $5 \mathrm{~cm}$ diameter openings was placed in the centre of each aquarium, so the fish could exit in any direction after the feed was supplied. Immediately after the fish left the shelter, it was removed from the aquarium and the consumption was recorded. 
The feeds were placed in each corner of the aquarium, equidistant from the centre and reallocated daily to avoid place selection (Figure 1). Twenty feedings per fish were recorded by a camera (Logitech C920 Carl Zeiss Tessar, Full HD 1080P 15 MB) with time spent feeding being analysed by SACAM software (Jorge et al., 2005). The feeding recordings took $1 \mathrm{hr}$, twice a day (8 and $20 \mathrm{hr}$ ) for each specimen after feeds were placed. After each recording, the aquarium was siphoned and partial water exchange was performed.

\section{3 | Experiment 2: Feeding rate and frequency assay}

To refine the feed management, a completely randomized trial was carried out in a $3 \times 2$ factorial scheme with three replicates. A total of 18 aquariums ( $60 \mathrm{~L}$ useful volume), with six specimens $(1.76 \pm 0.64 \mathrm{~g}$ and $5.48 \pm 0.67 \mathrm{~cm}$, subadults) each were used. Three feeding frequencies (one meal: at 8 p.m., two meals: at 8 a.m. and 8 p.m.; and three meals: at 8 a.m., 2 p.m. and 8 p.m.) and two feeding rates (5\% and $10 \%$ relative to live weight per day $-\mathrm{LW}$. day ${ }^{-1}$ ) were evaluated. The preferred feed as per the results from the experiment 1 corresponded to saline brine shrimp, which was used to feed fish for 60 days.

\section{4 | Experiment 3: Stocking density assay}

The best results from the previous experiments were used in the stocking density assay. A total of 150 animals $(1.71 \pm 0.23 \mathrm{~g}$ and $5.54 \pm 0.17 \mathrm{~cm}$, subadults) were used in 12 aquariums with



FIGURE 1 Schematic diagram of the experimental setup. The camcorder camera (W) was positioned at the centre of the set. The PVC (S) shelters were placed at the centre of each aquarium and the feed was provided to all four corners. Feed evaluated: Artemia (A), Shrimp (S), Mussel (M) and Fish (F)
$30 \mathrm{~L}$ of water (useful volume). Feeding was done with saline brine shrimp twice a day at $10 \% \mathrm{LW}$. day ${ }^{-1}$. Four stocking densities, 0.25 ; $0.50 ; 1.00$; and $2.00 \mathrm{~g} / \mathrm{L}$ in triplicate, were evaluated for 60 days.

\subsection{Evaluation of growth performance}

At the end of experiments 2 and 3 , all fish were measured and weighed to calculate the weight gain (WG = final weight - initial weight), length gain (LG = final length - initial length), specific growth rate by weight $\left(\mathrm{SGR}_{\mathrm{w}}=100 \times(\right.$ In final weight/ In initial weight)/days of experiment) and length $\left(\mathrm{SGR}_{1}=100 \times(\right.$ In final length - In initial length $) /$ days of experiment $)$, uniformity in weight (UW) and length (UL; Furuya, Souza, Furuya, Hayashi, \& Ribeiro, 1998) and relative condition factor ( $\mathrm{Kr}=\mathrm{ob}-$ served weight/expected weight; Le Cren, 1951). Furthermore, the survival rate was calculated at the end of the experiment.

\subsection{Statistical analysis}

Preference feed data were submitted to the non-parametric KruskalWallis test and the medians were compared by Dunn's test. After the verification of the normality and homoscedasticity premises (Shapiro-Wilk and Bartlett's test, respectively), growth performance data in experiment 2 were submitted to two-way ANOVA $(p<0.05)$ followed by post hoc Tukey's test $(p<0.05)$, with feeding rate and frequency being considered as factors. Growth performance as affected by distinct densities was analysed through one-way ANOVA followed by Tukey's test (Zar, 1999). The results are presented as mean \pm standard deviation (SD). All statistical analyses were performed using ASSISTAT 7.7 Software (Silva \& Azevedo, 2016).

\section{3 | RESULTS}

The water quality parameters from all experiments are presented in Table 1.

In the preliminary feed preference test (acclimation period), the vegetables were not consumed by the fish, except for the potato in rare occasions. The fish did not present buccal scraping movements upon the feeds; however, animals did consume the surrounding feed particles.

In the definitive feed preference test (Experiment 1), the zebra pleco showed preference for artemia (higher median in feeding time) followed by fish, shrimp and mussels (Table 2).

No significant interaction occurred between feeding frequency and rate (FF $\times F R, p>0.05)$. The animals fed twice daily had higher WG and LG (Table 3), and the fish submitted to the feeding rate of $10 \% \mathrm{LW} \mathrm{day}^{-1}$ presented higher $(p<0.05)$ length gain than those fed $5 \% \mathrm{LW}_{\text {day }}{ }^{-1}$.

In the experiment 3, only SGRw and SGRI presented significant differences with higher values observed at the density of $2 \mathrm{~g} / \mathrm{L}$ (Table 4).

During the experimental period, no mortality was observed. 
TA B LE 1 Mean values $( \pm S D)$ of $\mathrm{pH}$, temperature $\left({ }^{\circ} \mathrm{C}\right)$, dissolved oxygen (DO mg/L) conductivity $(\mu \mathrm{S} / \mathrm{cm})$ and total ammonia nitrogen (TAN) $\left(\mathrm{NH}_{4}^{+}+\mathrm{NH}_{3}^{-}-\mathrm{N} \mathrm{mg} \mathrm{L}^{-1}\right)$ from Hypancistrus zebra experiments

\begin{tabular}{llllll} 
Experiments & $\mathrm{pH}$ & Temperature & DO & Cond. & TAN \\
Feed preference & $6.21 \pm 0.26$ & $27.5 \pm 0.8$ & $6.92 \pm 0.14$ & $11.75 \pm 1.46$ & $0.09 \pm 0.02$ \\
\hline Feed management & $7.23 \pm 0.56$ & $28.6 \pm 0.5$ & $7.05 \pm 0.71$ & $12.63 \pm 0.06$ & $0.05 \pm 0.07$ \\
Stocking density & $7.01 \pm 0.78$ & $28.6 \pm 0.6$ & $7.12 \pm 0.38$ & $14.22 \pm 0.13$ & $0.02 \pm 0.02$ \\
\hline
\end{tabular}

TAB LE 2 Feeding time (in minutes) of Hypancistrus zebra on different diets

\begin{tabular}{llll} 
& \multicolumn{2}{l}{ Feeding time $(\min )$} & \\
\cline { 2 - 4 } Feeds & Median & $\mathrm{Z}$ & $p$-Value \\
Artemia & $15.5 \mathrm{a}$ & 9.64 & 0.033 \\
\hline Fish & $10.8 \mathrm{~b}$ & 5.00 & 0.997 \\
Shrimp & $9.9 \mathrm{~b}$ & 2.57 & 0.690 \\
Mussel & $8.1 \mathrm{~b}$ & -0.6 & 0.047 \\
\hline
\end{tabular}

Note: Medians in the same column with distinct letters differ from each other by Dunn's test.

\section{4 | DISCUSSION}

Adequate nutrition and feeding of captive fish, mainly those under the risk of extinction, are important to secure welfare and successful breeding programmes, which in turn, could represent the continued existence of natural stocks and supply of the ornamental fish trade.

Feed preference tests allow for the identification of suitable alternative feeding of captive wild specimens (Dawkins, 2006; Sullivan et al., 2016), whereas better feed management practices will lead to improved zootechnical performance and yields (Jomori, Carneiro, Malheiros, \& Portella, 2003).

TA B LE 3 Mean values ( $\pm S D$ ) of weight (WG) and length gains (LG), specific growth rate for weight (SGRw) and length (SGRI), uniformity in weight (UW) and length (UL), relative condition factor ( $\mathrm{Kr}$ ) and survival (S) of Hypancistrus zebra juveniles submitted to different feeding rates and frequencies

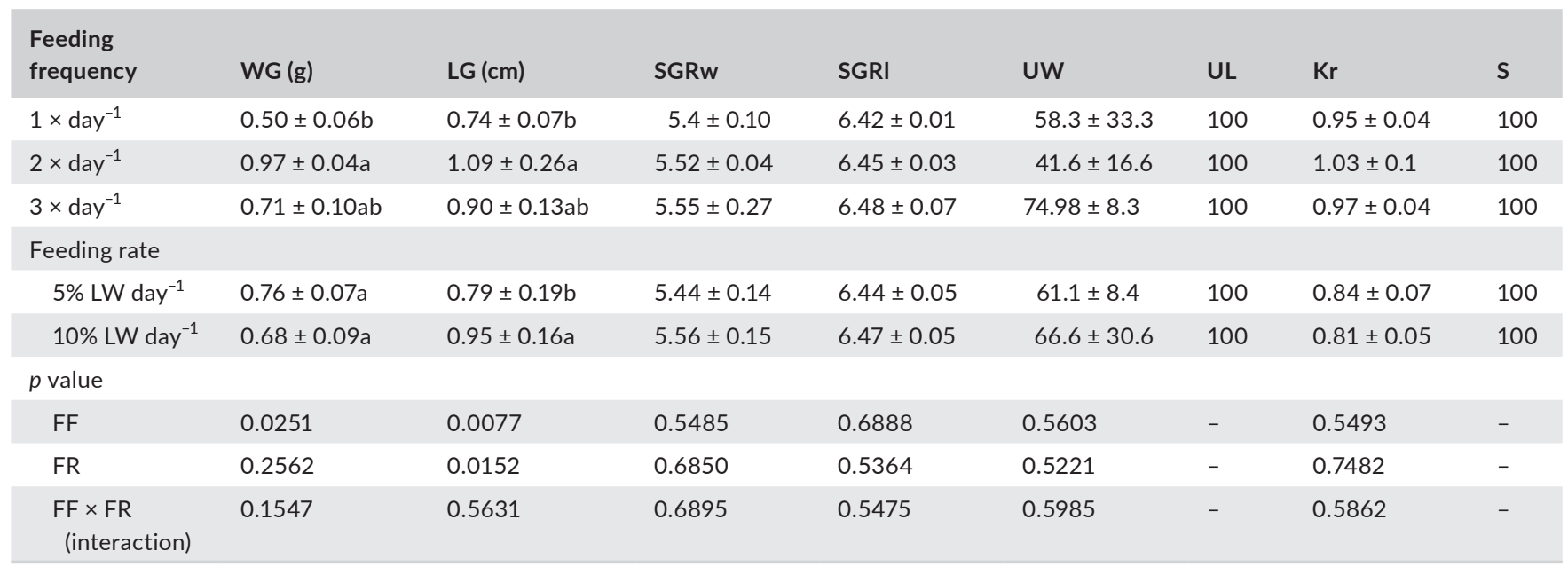

Note: When present, different letters in columns denote significant differences after two-way ANOVA and Tukey's test at $5 \%$ probability.

TA B LE 4 Mean values ( $\pm S D$ ) of weight (WG) and length gains (LG), specific growth rate for weight (SGRw) and length (SGRI), uniformity in weight (UW) and length (UL), relative condition factor (Kr) and survival (S) of Hypancistrus zebra juveniles submitted to different stocking densities

\begin{tabular}{lllllllll} 
Densities & WG(g) & LG(cm) & SGRw & SGRI & UW & UL & Kr & S \\
\hline $0.25 \mathrm{~g} / \mathrm{L}$ & $0.59 \pm 0.02$ & $0.93 \pm 0.15$ & $5.04 \pm 0.05 \mathrm{c}$ & $6.28 \pm 0.01 \mathrm{c}$ & $73.3 \pm 11.5$ & 100 & $1.04 \pm 0.03$ & 100 \\
\hline $0.50 \mathrm{~g} / \mathrm{L}$ & $0.67 \pm 0.08$ & $0.87 \pm 0.16$ & $5.11 \pm 0.1 \mathrm{bc}$ & $6.32 \pm 0.03 \mathrm{bc}$ & $71.4 \pm 6.4$ & 100 & $0.93 \pm 0.05$ & 100 \\
\hline $1.00 \mathrm{~g} / \mathrm{L}$ & $0.70 \pm 0.02$ & $1.12 \pm 0.13$ & $5.26 \pm 0.02 \mathrm{~b}$ & $6.35 \pm 0.01 \mathrm{~b}$ & $68.8 \pm 7.6$ & 100 & $1.03 \pm 0.04$ & 100 \\
\hline $2.00 \mathrm{~g} / \mathrm{L}$ & $0.84 \pm 0.02$ & $1.31 \pm 0.11$ & $5.65 \pm 0.01 \mathrm{a}$ & $6.48 \pm 0.01 \mathrm{a}$ & $78.3 \pm 7.6$ & 100 & $1.01 \pm 0.02$ & 98.3 \\
\hline
\end{tabular}

Note: Different letters in columns indicate significant differences after one-way ANOVA and Tukey's test at $5 \%$ probability. 
Zebra pleco did not consume vegetables in this study, instead, it preferred Artemia sp. This feed preference is in line with the reports of Seidel (1996), who observed a predominant animalbased feed consumption of artemia, Daphnia sp. and bloodworms (Chironomidae) in this fish species. Gonçalves (2011) found 12 feed items in the wild zebra pleco digestive tract, seven of which corresponded to feed from animal origin, and two from vegetable-related sources, which corroborate the preference of zebra pleco for animalbased feed. The presence of sand, debris and unidentified material was also reported.

Other Loricariids such as Farlowella sp., Rineloricaria heteroptera and Ancistrus sp. (Sabino \& Zuanon, 1998), Hisonotus sp., Hypostomus ancistroides and Hypostomus nigromaculatus (Casatti, Langeani, \& Castro, 2001) and Hypostomus pyrineusi, Panaque nocturnus, P. cf. nigrolineatus and Pterygoplichthys disjunctivus (German, 2009) showed distinct feeding habits, consisting mainly on plant-based diets. Usually, the Loricariids use their disc-like modified lips for their fixation, scraping of the substrate and grazing of the algae adhered to rocks and trunks (Abelha, Agostinho, \& Goulart, 2001; Casatti et al., 2001; Garavello \& Garavello, 2004; Mazzoni, Rezende, \& Manna, 2010; Sabino \& Zuanon, 1998). Differently, the zebra pleco used the oral disc for fixation but not for scraping the feed, showing preference for the consumption of small surrounding feed particles.

Higher frequencies of feeding (two and three daily feeds) promoted an improved zootechnical performance compared to fish fed only one time day ${ }^{-1}$. These results corroborated studies on other species from the Siluriformes order, as Pseudoplatystoma corruscans, to which the feeding frequency of two times day $^{-1}$ is routinely used in semi-intensive and intensive rearing systems (Liranço, Romagosa, \& Scorvo-Filho, 2011). Two daily feeds were also indicated for a better larvae development of Rhinelepis aspera (Loricariid; Luz \& Dos Santos, 2010).

The best feeding rate for zebra pleco $\left(10 \% \mathrm{LW} \mathrm{day}^{-1}\right)$ was similar to that of the ornamental fish Trichogaster trichopterus, where the feeding rate of $9 \% \mathrm{LW} \mathrm{day}^{-1}$ promoted the highest values of length gain (LG), weight gain (WG), specific growth rate (SGR) and condition factor (Kr; Zuanon, Assano, \& Fernandes, 2004). Adequate stocking density is essential for the successful captive breeding of fish, since excessive crowding can render animals stressed (Conte, 2004), deteriorate the water quality (Sahoo et al., 2010), negatively affect health (Nomura et al., 2013), impair growth performance (Fujimoto et al., 2012; Iwama, Afonso, Todgham, Ackerman, \& Nakano, 2004) and increase the nutritional requirement (Lefrançois et al., 2001). However, in the highest density tested, no negative effects were observed in the growth and survival of zebra pleco in captivity conditions.

While studies on adequate stocking densities for the rearing of juvenile loricariids are scarce, it is widely accepted that the stocking density under captivity is expected to be at the highest to optimize the production costs (Ayroza, Romagosa, Ayroza, Scorvo Filho, \& Salles, 2011; Zuanon et al., 2011). Densities used in this study were not sufficient to result in poor water quality or negatively impact zebra pleco growth. In species such as the African catfish (Clarias gariepinus), the stocking density of $3.95 \mathrm{~g} / \mathrm{L}$ allowed for an increased final weight when compared to a higher density of $7.9 \mathrm{~g} / \mathrm{L}$ (Hossain, Beveridge, \& Haylor, 1998). Herein, the density of $2 \mathrm{~g} / \mathrm{L}$ was suitable for the maintenance of the captive zebra pleco. Nevertheless, other stocking densities should be investigated to evaluate if even higher densities could allow for the maintenance of a good growth performance or otherwise, would negatively affect zebra pleco growth. Further studies on specific and balanced feed composition and formulation to the different developmental stages of zebra pleco are necessary to refine and optimize the rearing of this fish.

\section{5 | CONCLUSION}

Under the experimental conditions used herein, zebra pleco H. zebra presented feed preference for artemia, and captive individuals should be maintained at a density of $2 \mathrm{~g} / \mathrm{L}$, fed two times a day, using a feeding rate of $10 \%$ live weight day $^{-1}$ for an improved rearing condition of this fish, which is an endemic and endangered Amazon species.

Our findings add crucial information to the still scarce body of knowledge regarding the adequate management of this species and could assist in the supply of healthy specimens to the ornamental fish market as well as future governmental programmes for the restocking of declining wild populations.

\section{ACKNOWLEDGEMENTS}

Authors are thankful to Norte Energia SA, Leme Engenharia and CNPq (406512/2012-4 and 305195/2016-6) for the funding of this project. We are grateful to CAPES for a PhD scholarship provided to F. M. Ramos and Poytara Company for the provision of the rations.

\section{ORCID}

Higo Andrade Abe (iD https://orcid.org/0000-0002-5717-9641

Luis André Luz Barbas iD https://orcid.org/0000-0002-2708-8909

\section{REFERENCES}

Abelha, M. C. F., Agostinho, A. A., \& Goulart, E. (2001). Trophic plasticity in freshwater fishes. Acta Scientiarum Biological Sciences, 23, 425-434. https://doi.org/10.4025/actascibiolsci.v23i0.2696

Ayroza, L. M. S., Romagosa, E., Ayroza, D. M. M. R., Scorvo Filho, J. D., \& Salles, F. A. (2011). Costs and profitability of juvenile Nile Tilapia breeding using different stocking densities in net cages. Revista Brasileira Zootecnia, 40, 231-239.

Carneiro, P. C. F., \& Mikos, J. D. (2005). Feeding frequency and growth of silver catfish, Rhamdia quelen, fingerlings. Ciência Rural, 35, 187-191.

Casatti, L., Langeani, F., \& Castro, R. (2001). Stream fishes of the Morro do Diabo State Park, Upper Paraná River basin, SP. Biota Neotropica, $1,1-15$.

Conte, F. S. (2004). Stress and the welfare of cultured fish. Applied Animal Behaviour Science, 86, 205-223. https://doi.org/10.1016/j.appla nim.2004.02.003 
Crescêncio, R., Ituassú, D. R., Roubach, R., Pereira Filho, M., Cavero, B. A. S., \& Gandra, A. L. (2005). Influence of feeding period on consumption and weight gain of pirarucu. Pesquisa Agropecuaria Brasileira, 40, 1217-1222.

Dawkins, M. S. (2006). A user's guide to animal welfare science. Trends Ecology \& Evolution, 21, 77-82. https://doi.org/10.1016/j. tree.2005.10.017

Fujimoto, R. Y., De Castro, M. P., De Moares, F. R., \& Ramos, F. M. (2012). Chromium supplementation and stocking density in Pacus. Revista Ciência Agraria, 54, 172-177.

Furuya, W. M., Souza, S. R., Furuya, V. R. B., Hayashi, C., \& Ribeiro, R. P. (1998). Dietas peletizada e extrusada para machos revertidos de tilápias do Nilo (Oreochromis niloticus) na fase de terminação. Ciência Rural, 28, 483-487.

Garavello, J. C., \& Garavello, J. P. (2004). Spatial distribution and interaction of four species of the catfish genus Hypostomus lacépède with bottom of rio São Francisco, Canindé do São Francisco, Sergipe, Brazil (Pisces, Loricariidae, Hypostominae). Brazilian Journal of Biology, 64, 103-141. https://doi.org/10.1590/S1519-69842004000400006

Gerking, S. D. (1994). Feeding ecology of fish (Vol. 597, p. 416). San Diego, CA: Academic Press.

German, D. P. (2009). Inside the guts of wood-eating catfishes: Can they digest wood? Journal of Comparative Physiology B, 179, 1011-1023. https://doi.org/10.1007/s00360-009-0381-1

Gonçalves, A. P. (2011). Ecologia e etnoecologia de Hypancistrus zebra (Siluriformes: Loricariidae) no rio Xingu, Amazônia brasileira. (p. 137). Federal University of Pará.

Gonçalves, A. P., Camargo, M., Carneiro, C. C., Camargo, A. T., De Paula, G. J. X., \& Giarrizzo, T. (2009). A Pesca de peixes ornamentais. In M. Camargo, \& R. Jr. Ghilardi (Eds.), Entre a terra, as águas, e os pescadores do médio Rio Xingu: Uma abordagem ecológica (pp. 235-264). Belém, Brazil: Eletronorte.

Hossain, M. A., Beveridge, M. C., \& Haylor, G. S. (1998). The effects of density, light and shelter on the growth and survival of African catfish (Clarias gariepinus Burchell, 1822) fingerlings. Aquaculture, 160, 251-258. https://doi.org/10.1016/S0044-8486(97)00250-0

Huntingford, F. A., Adams, C., Braithwaite, V. A., Kadri, S., Pottinger, T. G., Sandøe, P., \& Turnbull, J. F. (2006). Current issues in fish welfare. Journal of Fish Biology, 68, 332-372. https://doi. org/10.1111/j.0022-1112.2006.001046.x

Isbrücker, I. J. H., \& Nijssen, H. (1991). Hypancistrus zebra, a new genus and species of uniquely pigmented ancistrine loricariid fish from the Rio Xingu, Brazil (Pisces: Siluriformes: Loricariidae). Ichthyological Exploration Freshwaters, 1, 345-350.

ITC. International TRADE centre (2018). Statistics export product country: Ornamental fish. Retrieved from http://www.intracen.org/itc/market-info-tools/statistics-export-product-country/

Iwama, G., Afonso, L., Todgham, A., Ackerman, P., \& Nakano, K. (2004). Are hsps suitable for indicating stressed states in fish. Journal of Experimental Biology, 207, 15-19. https://doi.org/10.1242/jeb.00707

Jomori, R. K., Carneiro, D. J., Malheiros, E. B., \& Portella, M. C. (2003). Growth and survival of pacu (Piaractus mesopotamicus) (Holmberg, 1887) juveniles reared in ponds or at different initial larviculture periods indoors. Aquaculture, 221, 277-287.

Jorge, L. D. C., Laumann, R., Borges, M., Moraes, M. C. B., Cruz, R. A., Milare, B. N., \& Palhares, L. (2005). Software para Avaliação do Comportamento de Insetos. Embrapa Instrumentação Agropecuária. Circular Técnica, n. 30. Retrieved from https://www.infoteca.cnptia. embrapa.br/bitstream/doc/24762/1/CiT302005.pdf

Le Cren, E. D. (1951). The length-weight relationship and seasonal cycle in gonad weight and condition in the perch (Perca fluviatilis). Journal of Animal Ecology, 20, 201-219. https://doi.org/10.2307/1540

Lefrançois, C., Claireaux, G., Merciel, C., \& Aubin, J. (2001). Effect of density on the routine metabolic expenditure of farmed rainbow trout (Oncorhynchus mykiss). Aquaculture, 195, 269-277. https://doi. org/10.1016/S0044-8486(00)00559-7
Liranço, A. D. D. S., Romagosa, E., \& Scorvo-Filho, J. D. (2011). Growth performance of Pseudoplatystoma corruscans stocked in rearing systems: Semi-intensive (ponds) and intensive (cages). Ciência Rural, 41, 1-7.

LiveAquaria (2016). Quality aquatic life direct to your door. Retrieved from http://www.liveaquaria.com/product/aquarium-fish-supplies. $\mathrm{cfm} ? \mathrm{c}=830+837$

Luz, R. K., \& Santos, J. C. E. (2010). Effect of salt addition and feeding frequency on cascudo preto Rhinelepis aspera (Pisces: Loricariidae) larviculture. Journal of Applied Ichthyology, 26, 453-455. https://doi. org/10.1111/j.1439-0426.2009.01371.x

Mazzoni, R., Rezende, C. F., \& Manna, L. R. (2010). Feeding ecology of Hypostomus punctatus Valenciennes, 1840 (Osteichthyes, Loricariidae) in a costal stream from Southeast Brazil. Brazilian Journal of Biology, 70, 569-574. https://doi.org/10.1590/S151969842010000300013

MDIC (2017). Plataforma Aliceweb: Relatórios de dados de importação e exportação de peixes ornamentais de 1989 a 2017. Ministério, da Indústria, Comércio Exterior e Serviços - MDIC. Retrieved from http://aliceweb.mdic.gov.br

Nomura, D. V., Martins, M. L., Moraes, F. R. D., Ramos, F. M., Santos, R. F. B., \& Fujimoto, R. Y. (2013). Catch-and-release: Repetitive fishing, hematological variables and parasitism in the tambacu hybrid fish. Pesquisa Agropecuaria Brasileira, 48, 1058-1063.

Papoutsoglou, S. E., Tziha, G., Vrettos, X., \& Athanasiou, A. (1998). Effects of stocking density on behaviour and growth rate of European sea bass (Dicentrarchus labrax) juveniles reared in a cleoe circulated system. Aquaculture, 18, 138-144. https://doi.org/10.1016/ S0144-8609(98)00027-2

Rahmah, S., Kato, K., Yamamoto, S., Takii, K., Murata, O., \& Senoo, S. (2014). Improved survival and growth performances with photoperiod and feeding schedule manipulation in bagrid catfish Mystus nemurus (Cuvier \& Valenciennes 1840) larvae. Aquaculture Research, 45, 501-508. https://doi.org/10.1111/j.1365-2109.2012.03253.x

Rahman, M. A., Kazi Ahsan Habib, M., Amzad Hossain, S. M., Azad, O., \& Rayhan, M. Z. (2017). Impacts of stocking density and economic returns on the cage culture of stinging catfish, Heteropneustes fossilis. International Journal of Fisheries and Aquatic Studies, 5, 198-201.

Ramos, F. M., Araújo, M. L. G., Prang, G., \& Fujimoto, R. Y. (2015). Ornamental fish of economic and biological importance to the Xingu River. Brazilian Journal of Biology, 75, 95-98. https://doi. org/10.1590/1519-6984.02614BM

Ramos, F. M., Recuero, L. B., Silva, T. V. N., Fujimoto, R. Y., Lee, J. T., \& Torres, M. F. (2013). Shelter selection in the Amazonian zebra pleco, Hypancistrus zebra Isbrücker \& Nijssen, 1991 (Siluriformes: Loricariidae): Requirements in rearing conditions. Journal of Applied Ichthyology, 29, 927-929. https://doi.org/10.1111/jai.12176

Ribeiro, F. A. S., Carvalho Junior, J. R., Fernandes, J. B. K., \& Nakayama, L. (2008). Comércio brasileiro de peixes ornamentais. Panorama Da Aquicultura, 18, 54-59.

Ribeiro, F. A. S., Jorge, P. H., Fernandes, J. B. K., \& Sakomura, N. K. (2010). Stocking density to produce freshwater angelfish polycultured in ponds with amazona river prawn. Revista Caatinga, 23, 129-134.

Sabino, J., \& Zuanon, J. (1998). A stream fish assemblage in central Amazonia: Distribution, activity patterns and feeding behavior. Ichthyological Exploration Freshwaters, 8, 201-210.

Sahoo, S. K., Giri, S. S., Chandra, S., \& Sahu, A. K. (2010). Stocking density-dependent growth and survival of Asian sun catfish, Horabagrus brachysoma (Gunther 1861) larvae. Journal of Applied Ichthyology, 26 , 609-611. https://doi.org/10.1111/j.1439-0426.2010.01473.x

Sarkar, U. K., Lakra, W. S., Deepak, P. K., Nagi, R. S., Paul, S. K., \& Srivastava, A. (2006). Performance of different types of diets on experimental larval rearing of endangered Chitala chitala (Hamilton) in re-circulatory system. Aquaculture, 261, 141-150. https://doi. org/10.1016/j.aquaculture.2006.06.051 
Seidel, I. (1996). New information on the Zebra Pleco (p. 479). Tropical Fish Hobbist Magazine: Hypancistrus zebra.

Shoko, A. P., Limbu, S. M., \& Mgaya, Y. D. (2016). Effect of stocking density on growth performance, survival, production, and financial benefits of African sharptooth catfish (Clarias gariepinus) monoculture in earthen ponds. Journal of Applied Aquaculture, 28(3), 220-234. https ://doi.org/10.1080/10454438.2016.1188338

Silva, F. A. S., \& Azevedo, C. A. V. (2016). The Assistat Software Version 7.7 and its use in the analysis of experimental. African Journal of Agricultural Research, 11, 3733-3740. https://doi.org/10.5897/ AJAR2016.11522

Slight, D. J., Nichols, H. J., \& Arbuckle, K. (2015). Are mixed diets beneficial for the welfare of captive axolotls (Ambystoma mexicanum)? Effects of feeding regimes on growth and behavior. Journal of Veterinary Behavior, 10, 185-190. https://doi.org/10.1016/j. jveb.2014.09.004

Sullivan, M., Lawrence, C., \& Blache, D. (2016). Why did the fish cross the tank? Objectively measuring the value of enrichment for captive fish. Applied Animal Behaviour Science, 174, 181-188. https://doi. org/10.1016/j.applanim.2015.10.011
Volpato, G. L., Goncalves-de-Freitas, E., \& Fernandes-de-Castilho, M. (2007). Insights into the concept of fish welfare. Diseases of Aquatic Organisms, 75, 165-171. https://doi.org/10.3354/dao075165

Zar, J. H. (1999). Biostatistical analysis (p. 663). Bergen, NJ: Prentice-Hall. Zuanon, J. A. S., Assano, M., \& Fernandes, J. B. K. (2004). Performance of Tricogaster (Trichogaster trichopterus) Submitted to Different Feeding Levels and Stocking Densities. Revista Brasileira De Zootecnia, 33, 1639-1645.

Zuanon, J. A. S., Salaro, A. L., \& Furuya, W. M. (2011). Production and nutrition of ornamental fish. Revista Brasileira De Zootecnia, 40, 165-174.

How to cite this article: Menezes Ramos F, Abe HA, Martins Cordeiro CA, et al. Feed management and stocking density of the endangered wild zebra pleco: Implications for captive breeding. Aquac Res. 2019;00:1-7. https://doi.org/10.1111/ are.14197 